\title{
Diplomasi Publik Indonesia terhadap Vanuatu dalam Upaya Membendung Gerakan Separatisme Papua
}

\author{
Ahmad Sabir \\ Universitas Indonesia
}

\begin{abstract}
Abstrak
Penelitian ini menjelaskan tentang diplomasi publik Indonesia terhadap Vanuatu sebagai upaya penyelesaian isu separatisme di Papua. Penulis menggunakan teori diplomasi publik yang dikemukakakan oleh Leonard, Stead, dan Smewing (2002). Dalam teor ini, terdapat tiga dimensi dan empat tahapan capaian yang berperan sebagai indikator keberhasilan pelaksanaan diplomasi publik. Hasil dari penelitian ini menunjukkan bahwa diplomasi publik Indonesia untuk memengaruhi sikap politik Vanuatu atas isu separatisme Papua belum berhasil dilakukan, akibat belum optimalnya implementasi diplomasi publik Indonesia. Kegagalan ini ditunjukkan melalui sikap politik Vanuatu yang tetap mendukung gerakan separatis Papua. Setidaknya ada tiga faktor yang menyebabkan lemahnya diplomasi publik Indonesia terhadap Vanuatu, yaitu: (1) pelaksanaan diplomasi publik Indonesia yang masih didominasi aktor negara dan kurang melibatkan aktor non-negara; (2) tidak optimalnya implementasi tiga dimensi strategi diplomasi publik Indonesia; dan (3) kuatnya pengaruh doktrin Melanesian Renaissance dalam perpolitikan domestik Vanuatu. Walaupun demikian, penulis menilai bahwa Indonesia masih mempunyai peluang apabila mampu mengoptimalkan tiga dimensi dalam implementasi diplomasi publik, mengelola dan mengoordinasikan pelaksanaan diploması publik secara profesional, serta melibatkan lebih banyak aktor non-negara.
\end{abstract}

Kata kunci: Diplomasi Publik, Indonesia, Vanuatu, United Liberation Movement for West Papua (ULMWP), Gerakan Separatis Papua.

This research explains Indonesia's public diplomacy towards Vanuatu in the context of the Indonesian government's efforts to resolve separatism issue in Papua. The analysis in this paper uses theory of Public Diplomacy by Leonard, Stead, and Smewing (2002). The theory contains three dimensions and four stages of achievement that serve as indicators to implement public diplomacy. The results showed that Indonesia's public diplomacy has failed to shape Vanuatu's political stances on Papuan separatism issue, due to the lack of the implementation of Indonesia's public diplomacy. Vanuatu still staunchly supports Papua separatist movement. There are at least three reasons closely related to the weakness of Indonesia's public diplomacy towards Vanuatu: (1) the conduct of Indonesia's public diplomacy was dominated by state actor and did not involve the non-state actors; (2) the three dimensions of Indonesian public diplomacy have not been optimally conducted; and (3) the strong influence of Melanesian Renaissance doctrine in Vanuatu's domestic politics. Nevertheless, the author considers that Indonesia still has the opportunity if they are able to optimize the three dimensions in conducting public diplomacy, manage, and coordinate the conduct of public diplomacy profesionally, and involve more non-state actors.

Keywords: Public Diplomacy, Indonesia, Vanuatu, United Liberation Movement for West Papua (ULMWP), Papua Separatist Movement. 
Isu separatisme Papua merupakan salah satu persoalan serius yang dihadapi Indonesia saat ini. Dalam sejarah separatisme di Indonesia, konflik dengan Organisasi Papua Merdeka (OPM) merupakan konflik terbesar yang pernah dihadapi Indonesia (Puspitasari 2010). Pergerakan OPM yang sebelumnya terpecah-pecah dalam berbagai faksi perlawanan kini semakin terkonsolidasi, solid, dan rapi (Tebay 2016). Kondisi ini menjadi tantangan tersendiri bagi pemerintah Indonesia dalam meredam gerakan separatis Papua yang mengancam keutuhan Negara Kesatuan Republik Indonesia (NKRI).

Sementara di sisi lain, berdasarkan proyeksi kekuatan Indonesia tahun 2014 - 2019 yang dikeluarkan oleh Badan Intelijen Negara (BIN), kemampuan pertahanan Indonesia dinilai paling lemah ketika dihadapkan pada ancaman OPM dibandingkan dengan ancaman aktor non-negara lainnya (BIN 2014). Adapun daftar ancaman dari aktor non-negara dan kemampuan pertahanan Indonesia dapat dilihat pada grafik di bawah ini.

\section{Grafik Ketahanan Indonesia dalam Menghadapi Anca- man Aktor-aktor Non-Negara}

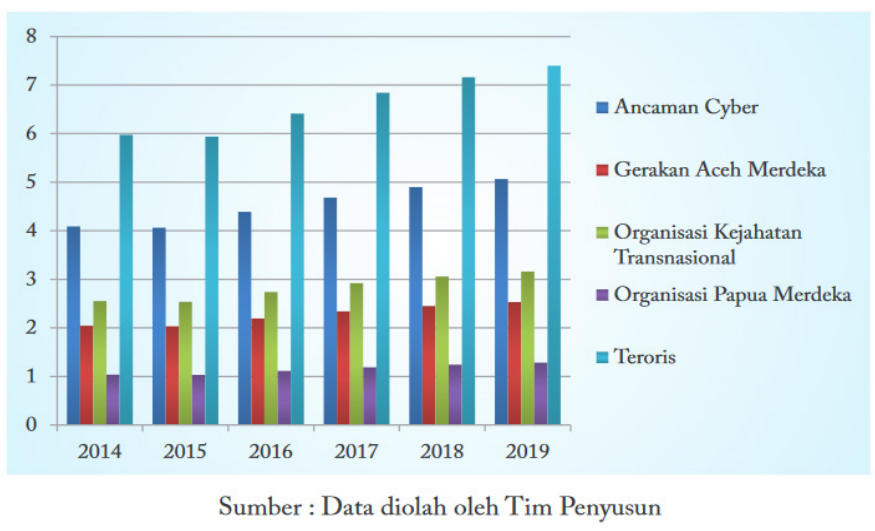

Sumber: Badan Intelijen Negara Republik Indonesia

Dalam grafik tersebut terlihat bahwa Indonesia lebih siap menghadapi ancaman dari teroris, cyber, organisasi kejahatan transna- 
sional, dan Gerakan Aceh Merdeka (GAM) apabila dibandingkan dengan ancaman dari OPM. Hal ini berarti bahwa gerakan separatisme Papua merupakan ancaman terbesar yang dapat dihadapi oleh Indonesia sepanjang tahun $2014-2019$.

Tulisan ini membahas upaya diplomasi publik Indonesia terhadap Vanuatu dalam isu separatisme Papua. Penelitian ini menggunakan metode penelitian kualitatif, deskriptif analitik, dan menerapkan studi pustaka sebagai teknik pengumpulan data. Dengan menggunakan teori diplomasi publik dari Leonard, Stead, dan Smewing (2002), penulis menjelaskan mengenai kelemahan diplomasi publik Indonesia yang belum mampu menghentikan dukungan Vanuatu terhadap gerakan separatis Papua. Penulis juga menjelaskan sejauh mana pencapaian diplomasi publik Indonesia terhadap Vanuatu.

\section{Separatisme di Papua}

Dari berbagai ancaman terhadap negara, separatisme menjadi salah satu ancaman utama bagi Indonesia karena menyangkut masalah kedaulatan wilayah. Pemisahan diri dari negara berdaulat (secession), pembentukan wilayah sendiri (fragmentation), pendirian pemerintahan otonom (autonomy), dan penentuan nasib sendiri (self determination) adalah konsep-konsep yang menjadi cakupan dari separatisme (McHenry 2009). Dalam sejarah bangsa Indonesia, gerakan separatis telah ada sejak awal kemerdekaan dan beberapa diantaranya masih eksis hingga saat ini meskipun tidak secara jelas tampak melakukan perlawanan seperti pada awal kemunculannya. Beberapa diantaranya adalah Gerakan Aceh Merdeka (GAM) di Aceh, Republik Maluku Selatan (RMS) di Maluku, dan Organisasi Papua Merdeka (OPM) di Papua.

Gerakan separatis di Papua menjadi salah satu isu yang mendapatkan perhatian khusus pemerintah Indonesia. Gerakan ini menghendaki pemisahan wilayah Papua yang saat ini terbagi menjadi dua provinsi - Papua dan Papua Barat. Penyebab berkembangnya gerakan ini adalah kekecewaan masyarakat Papua terhadap pemerintah pusat dalam menangani berbagai permasalahan di Papua. Permasalahan-permasalahan tersebut teridentifikasi dalam laporan hasil kunjungan Komisi I DPR RI dengan berbagai pemangku kepentingan pada tahun 2012 di Papua, antara lain: 1) menurunnya 
tingkat kepercayaan masyarakat Papua terhadap pemerintah pusat dan daerah; 2) menguatnya isu politik dan historis tentang proses integrasi Papua; 3) tidak efektifnya Unit Percepatan Pembangunan Papua dan Papua Barat (UP4B) dalam akselerasi pembangunan; 4) lumpuhnya pemerintah provinsi akibat kisruh pilkada dan lemahnya kinerja pemerintah daerah kabupaten/kota; dan 5) meluasnya aksi kekerasan bersenjata di Papua (Papua Review, 2012, hal. 8). Kelompok separatis ini menamakan wilayah Papua sebagai West Papua atau Papua Barat.

Wilayah Papua secara resmi bergabung dengan Indonesia sejak disepakatinya Perjanjian New York (New York Agreement) pada tanggal 15 Agustus 1962, diikuti dengan Penentuan Pendapat Rakyat (Pepera) pada tahun 1969 yang hasilnya disahkan dalam Sidang Umum PBB pada tanggal 19 November 1969. Walaupun demikian, perlawanan dari kelompok separatis di Papua terus terjadi hingga saat ini. Kelompok separatis tersebut menilai bahwa Perjanjian New York dan Pepera 1969 "cacat hukum" dan melanggar hak-hak asasi rakyat Papua karena tidak dilakukan sesuai dengan prosedur yang berlaku, yakni one man one vote melainkan melalui sistem perwakilan (Susiyanto 2016). Dalam perkembangannya, kelompok separatis Papua yang sebelumnya bergerak secara sporadis dan tidak terkoordinasi, menjadi semakin solid dan terkonsolidasi dalam mencapai tujuannya yaitu melepaskan diri dari Indonesia dan membentuk negara sendiri dengan nama Papua Barat (West Papua).

Semakin terkonsolidasinya perlawanan kelompok separatis Papua ini ditunjukkan dengan pembentukan United Liberation Movement for West Papua (ULMWP) yang menyatukan faksi-faksi perjuangan OPM antara kelompok bersenjata dan faksi politik. Kehadiran ULMWP dimaksudkan agar upaya pemerdekaan Papua lebih terkoordinasi untuk meraih dukungan politik dari masyarakat internasional (ULMWP 2017). ULMWP dideklarasikan pada tanggal 7 Desember 2014 di Port Vila, Republik Vanuatu, dan memiliki tugas utama untuk mengampanyekan Papua merdeka (free West Papua campaign) serta melakukan lobi-lobi politik untuk mendapatkan dukungan dari berbagai negara, terutama di kawasan Pasifik Selatan.

Persoalan Papua lantas tidak lagi terbatas pada urusan domestik, namun telah berkembang menjadi isu internasional. Hal ini tidak 
terlepas dari peran ULMWP dan negara-negara di kawasan Pasifik Selatan yang secara implisit maupun eksplisit telah memfasilitasi dan membantu proses internasionalisasi isu Papua. Selain itu, kepentingan asing di Papua juga turut andil dalam menarik perhatian dunia atas Papua, seperti Amerika Serikat, Australia, Kanada, Cina, Jepang, dan India yang masing-masing memiliki kepentingan bisnis di tanah Papua.

Dengan mengusung isu-isu non-tradisional seperti HAM dan demokrasi, kampanye Papua merdeka mendapat simpati dari masyarakat internasional khususnya para pegiat HAM. Kelompok separatis Papua bahkan berhasil membuka kantor perwakilan OPM di beberapa negara yaitu, Papua Nugini (Port Moresby), Australia (Perth), Belanda (The Hague), dan Inggris (Oxford), serta Vanuatu (Port Vila) yang secara khusus menjadi lokasi kantor ULMWP. Kendati kampanye Papua Merdeka dilakukan hingga ke Eropa, pusat pergerakan dan konsolidasinya tetap dipusatkan di kawasan Pasifik. Sebagai dampaknya, beberapa negara di kawasan Pasifik menunjukkan sikap pro terhadap upaya pemerdekaan Papua.

\section{Dukungan Vanuatu terhadap Separatisme Papua}

Vanuatu menjadi negara yang paling vokal dan tegas menyatakan dukungannya terhadap gerakan Papua Merdeka (Kemenlu 2017). Dengan dalih persamaan ras (Melanesian Brotherhood), Vanuatu memfasilitasi terbentuknya ULMWP dan menggalang dukungan dari negara Pasifik lainnya untuk kampanye politik Papua Merdeka dengan memanfaatkan organisasi sub-regional di kawasan Pasifik, seperti Melanesian Spearhead Group (MSG). Vanuatu sendiri merupakan salah satu penggagas berdirinya MSG.

Kepentingan Vanuatu di Papua secara antropologis didasari oleh hubungan etnis yang cukup erat, yaitu Melanesian Connection. Kedekatan etnis inilah yang menjadi salah satu sumber penyebab masifnya dukungan Vanuatu terhadap upaya pemerdekaan Papua. Kepentingan Vanuatu dalam dukungan ini didasarkan pada dua hal, yaitu politik domestik dan orientasi kekuasaan. Pada politik domestik, kebijakan-kebijakan luar negeri dari Vanuatu dipengaruhi oleh kelompok-kelompok kepentingan yang pro terhadap gerakan kemerdekaan Papua. Pengaruh dari politik domestik ini berkembang 
menjadi dua level, yaitu level nasional dan level internasional. Pada level nasional, kelompok-kelompok ini menekan pemerintah Vanuatu untuk mewujudkan aspirasi mereka dalam sebuahkebijakan politik dan hal tersebut berhasil dilakukan (Temaluru 2016). Oleh karena itu, orientasi politik luar negeri Vanuatu berjalan selaras dengan tuntutan politik dalam negeri.

Vanuatu juga memiliki kepentingan tersendiri untuk menjadi pemimpin regional dengan mengusung paham identitas Melanesian Renaissance. Paham ini mengangkat isu dekolonisasi bagi bangsa Melanesia yang belum merdeka sebagai bahan utama untuk menarik simpati internasional. Bergeraknya mekanisme politik domestik Vanuatu yang seperti itu merupakan hasil dari persinggungan prinsip Sosialisme Melanesia yang merupakan gabungan dari beberapa prinsip seperti komunalisme, saling berbagi, dan kepedulian sesama. Nilai-nilai yang dibawa dari Sosialisme Melanesia ini kemudian mencerminkan perubahan-perubahan revolusioner yang radikal pada bidang sosial, ekonomi, dan struktur politik secara cepat (Temaluru 2016).

Dukungan Vanuatu terhadap gerakan separatisme Papua diaktualisasikan dalam berbagai forum internasional. Vanuatu gencar menyuarakan persoalan pelanggaran Hak Asasi Manusia (HAM) di Papua yang bertujuan untuk menyudutkan Indonesia. Penulis mencatat beberapa peristiwa yang menunjukkan sikap berseberangan Vanuatu dengan Indonesia dalam isu separatisme Papua, diantaranya dalam sidang tahunan ke-68 Majelis Umum PBB pada tanggal 28 September 2013 di New York, Amerika Serikat. Dalam sidang tersebut, Vanuatu menyatakan bahwa Indonesia bertanggung jawab atas ratusan ribu orang Papua yang disiksa dan dibunuh (Dorney 2013). Selain itu, dalam sidang Dewan HAM PBB ke-25 di Jenewa, Swiss, pada tanggal 4 Maret 2014, Vanuatu meminta PBB untuk mengirim utusan menyelidiki dugaan pelanggaran HAM di Papua (ABC News 2014).

Selanjutnya, dalam Sidang Tahunan Majelis Umum PBB ke-71 di New York, Amerika Serikat tanggal 27 September 2016, Vanuatu menyampaikan keperihatinan atas pelanggaran HAM berat yang terjadi di Papua dan menyerukan pembebasan bagi West Papua untuk menentukan nasib sendiri (Rappler 2017). Di Sidang Dewan HAM 
PBB Sesi ke-34 di Jenewa, Swiss, tanggal 3 Maret 2017, Vanuatu membacakan pidato atas nama tujuh negara kepulauan di kawasan Pasifik yang berisi desakan kepada PBB untuk segera melakukan penyelidikan atas dugaan pelanggaran HAM yang dilakukan Indonesia di Papua (Rahman 2017).

Isu separatisme Papua juga dijadikan komoditas politik oleh elit-elit politik (non-state actor) di Vanuatu. Dalam beberapa kasus, isu separatisme Papua bahkan dimanfaatkan untuk menyerang lawan politik (Temaluru 2016). Hal ini dimungkinkan karena isu separatisme Papua yang mendapat perhatian khusus dari masyarakat Vanuatu, mulai dari elit hingga warga biasa, dari tingkat suku dan desa hingga pemuka agama (Temaluru 2016). Salah satu mantan Perdana Menteri Vanuatu, Sato Kilman, bahkan mendapatkan mosi tidak percaya dari parlemen Vanuatu pada tahun 2013, karena dianggap terlalu dekat dengan Indonesia. Parlemen Vanuatu pada saat itu meyakini bahwa Indonesia bertanggung jawab atas berbagai dugaan pelanggaran HAM di Papua.

\section{Diplomasi Publik Indonesia terhadap Vanuatu dalam Isu Separatisme Papua}

Indonesia sebenarnya sudah cukup lama menyadari kecenderungan Vanuatu untuk mendukung kemerdekaan Papua. Namun, baru beberapa tahun terakhir Indonesia menanggapinya secara serius, seiring semakin vokalnya Vanuatu di berbagai forum internasional serta semakin terinternasionalisasinya isu separatisme. Indonesia lantas mulai melakukan pendekatan dengan Vanuatu, salah satunya melalui diplomasi publik dengan memanfaatkan instrumen kerja sama ekonomi, teknologi, pelatihan, beasiswa, pembangunan, pertanian, peternakan dan lain-lain (Buku Diplomasi 2014). Indonesia juga memberikan bantuan luar negeri senilai USD 2 juta ketika Vanuatu terkena dampak yang cukup parah dari Badai Pam Pam (Cylone Pam) yang menerpa negara-negara di kawasan Pasifik.

Kendati demikian, upaya diplomasi publik Indonesia terhadap Vanuatu tampaknya belum berhasil mengondisikan negara tersebut untuk mendukung penuh kedaulatan Indonesia atas Papua. Hal ini dibuktikan dengan fakta bahwa Vanuatu masih memberikan dukungannya terhadap gerakan separatis Papua. 
Vanuatu beserta sejumlah negara di Pasifik Selatan bahkan secara terang-terangan menyatakan dukungannya atas pemerdekaan Papua dengan meminta PBB melakukan investigasi serta menyerukan agar Papua Barat diberikan hak penentuan nasib sendiri dalam Sidang Tahunan Majelis Umum PBB ke-71 di New York, Amerika Serikat (Rappler 2017). Mencermati hal tersebut, penulis mengidentifikasi kelemahan dalam praktik diplomasi publik yang dijalankan Indonesia terhadap Vanuatu.

Identifikasi dilakukan dengan menggunakan teori diplomasi publik yang diperkenalkan oleh Leonard, Stead, dan Smewing (2002) yang mencakup tiga dimensi diplomasi publik dan empat tahapan pencapaian tujuan diplomasi publik. Tiga dimensi diplomasi publik digunakan sebagai pisau analisis untuk mengetahui penyebab dari kelemahan diplomasi publik Indonesia terhadap Vanuatu, sedangkan empat tahapan pencapaian tujuan diplomasi publik digunakan untuk mengukur sejauh mana capaian dalam pelaksanaan diplomasi publik.

Dimensi pertama adalah manajemen berita, yaitu sikap atau respon Indonesia dalam menanggapi berita yang muncul dari Vanuatu tentang isu separatisme Papua. Pada dimensi ini, Indonesia melakukan beberapa langkah untuk meluruskan kesalahan persepsi publik Vanuatu dan publik internasional yang secara umum muncul akibat kesalahan informasi. Upaya manajemen berita oleh pemerintah Indonesia lantas dijalankan dengan menyampaikan informasi dan data-data yang berkaitan dengan isu Papua.

Langkah pertama yang diambil Indonesia adalah membantah tuduhan-tuduhan Vanuatu dan menyatakan bahwa tuduhan tersebut tanpa bukti dan bersifat politis. Contohnya, Indonesia menegaskan bahwa pintu informasi di Papua sudah dibuka lebar oleh Indonesia. Hal ini dilakukan untuk membantah tuduhan yang menyebutkan bahwa jurnalis asing tidak diperbolehkan masuk ke Papua. Bantahan ini selanjutnya dipertegas dengan mengundang perwakilan negara-negara anggota MSG untuk datang dan melihat langsung kondisi Papua, meskipun undangan tersebut ditolak dan diboikot oleh Vanuatu (CNN Indonesia 2017). 
Langkah kedua yang dilakukan oleh pemerintah Indonesia adalah menyiarkan dan mempublikasikan bantahan-bantahan tersebut ke berbagai media nasional dan internasional. Langkah ini dapat dilihat pada berita terkait pernyataan juru bicara Sekjen PBB tahun 2016 yang membantah adanya laporan tentang pelanggaran HAM di Papua yang diserahkan secara resmi ke Sekjen PBB, Ban Ki-moon, oleh pihak-pihak yang mendukung kemerdekaan Papua. Juru bicara Sekjen PBB menyebutkan bahwa isu tersebut disebarluaskan oleh kelompok anti-pembangunan di Papua (Kemenlu 2016).

Upaya manajemen berita yang ketiga adalah merilis sebuah laporan yang berjudul "No Genocide in West Papua" pada tahun 2016 (Kemenlu, 2016). Dalam laporan ini, pemerintah Indonesia menjabarkan kondisi Papua dalam bentuk data statistik, fakta-fakta pertumbuhan ekonomi dan pembangunan, fakta-fakta tentang dinamika politik di Papua, serta perjalanan berdarah kelompok separatis Papua.

Merujuk pada penjelasan tersebut, dapat dikatakan bahwa dimensi manajemen berita telah dilakukan oleh aktor-aktor diplomasi Indonesia baik aktor negara yaitu pemerintah Indonesia maupun aktor non-negara (khususnya media). Kendati demikian, penulis menilai bahwa pelaksanaan strategi ini belum optimal dilakukan, salah satunya ditunjukkan dengan lambannya respon pemerintah maupun media Indonesia terhadap setiap pemberitaan atau propaganda dari kelompok separatis Papua maupun pendukungnya. Selain itu, dari aspek timeline, pelaksanaan manajemen berita Indonesia terhadap Vanuatu baru terlihat sejak tahun 2013, yaitu sejak Vanuatu semakin gencar dan vokal "menyerang" Indonesia dalam berbagai forum regional maupun internasional.

Dimensi kedua adalah komunikasi strategis, yakni upaya proaktif untuk menciptakan agenda pemberitaan melalui serangkaian aktivitas dan kegiatan yang didesain sedemikian rupa untuk memengaruhi persepsi publik (Leonard, Stead, dan Smewing 2002). Dalam dimensi ini, langkah yang dilakukan Indonesia adalah mengembangkan narasi bahwa ras Melanesia di Indonesia bukan hanya orang Papua, melainkan ada juga etnis Maluku dan Timor (NTT). Pesan yang terkandung dalam narasi ini cukup strategis karena dapat membendung narasi kampanye Papua merdeka yang mengklaim dirinya se- 
bagai satu-satunya ras Melanesia di wilayah NKRI sehingga secara ras dan budaya berbeda dan bukan bagian dari bangsa Indonesia.

Penyampaian pesan strategis tersebut dilakukan dengan membentuk Indonesian Melanesian Brotherhood atau Persaudaraan Masyarakat Melanesia Indonesia (Melindo) pada tanggal 7 Oktober 2015 di Ambon, Provinsi Maluku serta menyelenggarakan kegiatan Festival Budaya Melanesia VI pada tanggal 26-30 Oktober 2015 di Kupang, Provinsi NTT. Aktor yang terlibat dalam pelaksanaan komunikasi strategis ini masih didominasi oleh aktor negara (first track) yakni pemerintah Indonesia. Dominasi peran pemerintah ditunjukkan mulai dari inisiasi kegiatan, perencanaan, hingga pelaksanaan Melanesian Cultural Festival maupun pembentukan Indonesian Melanesian Brotherhood yang semuanya dijalankan di bawah koordinasi Kementerian Pendidikan dan Kebudayaan RI. Kendati demikian, pelaksanaan Melanesian Cultural Festival 2015 sejatinya telah melibatkan sejumlah akademisi, analis budaya, dan wartawan/media (Kemdikbud, 2015).

Dimensi ketiga adalah membangun relasi, yang berperan dalam menciptakan pemahaman bersama sehingga masing-masing pihak mengerti cara pandang satu sama lain, khususnya dalam mendiskusikan isu-isu yang lebih spesifik, seperti isu separatisme Papua (Leonard, Stead dan Smewing 2002). Dalam hal ini, Indonesia menjalin berbagai kerja sama dengan Vanuatu dalam isu-isu non-tradisional seperti perubahan iklim, pembangunan, bencana alam, dan energi. Selain itu, Indonesia juga melaksanakan program di bidang pendidikan dan ekonomi kerakyatan melalui pelatihan teknis yang melibatkan peserta dari Vanuatu dan negara anggota MSG lainnya. Indonesia juga membentuk mekanisme kerja sama di bidang ekonomi melalui partisipasi aktif Indonesia dalam Kerja sama SelatanSelatan (KSS) yang merupakan bentuk kerja sama pembangunan antar negara berkembang untuk membangun kemandirian kolektif. Pada tahun 2013, pemerintah Indonesia memprioritaskan negaranegara di kawasan Pasifik Selatan sebagai penerima bantuan KSS.

Pada dimensi ini, aktor yang terlibat dalam pelaksanaan diplomasi publik praktis hanyalah aktor negara. Tidak terlihat adanya peran serta dari aktor non negara pada dimensi membangun relasi, baik oleh civil society, LSM, bisnis, media maupun lembaga swasta lain- 
nya. Dari aspek waktu, upaya membangun relasi dengan Vanuatu baru telihat intens dilakukan Indonesia pada tahun 2013, meskipun hubungan bilateral kedua negara telah terjalin sejak tahun 1995. Penulis menilai bahwa hal ini baru dilakukan karena isu Papua kian muncul ke publik internasional pada tahun-tahun tersebut. Maka dari itu, Indonesia baru mengarahkan politik luar negerinya ke kawasan Pasifik Selatan pada periode tersebut, khususnya terhadap Vanuatu yang dianggap memainkan peran penting dalam internasionalisasi isu Papua.

\section{Pencapaian Diplomasi Publik Indonesia terhadap Vanu- atu dalam Isu Papua}

Untuk mengukur pencapaian diplomasi publik Indonesia terhadap Vanuatu, maka penulis menggunakan empat tahapan pencapaian diplomasi publik yang dikemukakan oleh Leonard, Stead, dan Smewing (2002) yaitu:(1) adanya peningkatan keakraban masyarakat Vanuatu terhadap Indonesia; (2) peningkatan apresiasi masyarakat Vanuatu terhadap Indonesia; (3) pelibatan masyarakat Vanuatu dalam program-program atau aktivitas yang diselenggarakan Indonesia; dan (4) pengaruh dari Indonesia terhadap sikap politik masyarakat Vanuatu terhadap isu Papua.

Penulis menilai bahwa diplomasi publik Indonesia terhadap Vanuatu dalam isu Papua telah mencapai tahap pertama yaitu peningkatan keakraban masyarakat kedua negara. Hal ini ditandai dengan terpenuhinya kriteria-kriteria seperti meningkatnya pengetahuan publik Vanuatu tentang Indonesia, adanya perbaikan citra dan informasi tentang Indonesia, dan penampikan opini-opini negatif. Kegiatan diplomasi publik Indonesia yang dapat dikategorikan sebagai upaya untuk mencapai tahapan ini adalah dibukanya hubungan diplomatik dengan Vanuatu pada 3 Juli 1995. Hubungan diplomatik secara otomatis memperkenalkan Indonesia pada masyarakat Vanuatu melalui kehadiran perwakilan pemerintah di negara tersebut. Dalam dokumen yang menandai hubungan bilateral kedua negara, salah satu komitmen yang disepakati adalah memperkuat hubungan persahabatan antara pemerintah dan rakyat Indonesia dan Vanuatu (Kemenlu 1995). Selain itu, Indonesia juga berupaya meluruskan informasi dan persepsi yang dikembangkan oleh Vanuatu dalam beberapa forum internasional, yakni melalui berbagai publikasi di 
berbagai media milik pemerintah dan swasta, termasuk diantaranya dengan merilis laporan tentang kondisi nyata Papua yang berjudul "No Genocide in West Papua" pada tahun 2016. Indonesia juga mengembangkan narasi bahwa ras Melanesia di Indonesia bukan hanya etnis Papua,tetapi juga mencakup etnis Maluku dan Timor (NTT) melalui kegiatan Festival Budaya Melanesia dan pembentukan Persaudaraan Melindo.

Penulis selanjutnya menilai bahwa tahapan kedua pencapaian diplomasi publik belum sepenuhnya tercapai. Hal ini dibuktikan dengan masih gencarnya tudingan Vanuatu atas pelanggaran HAM oleh militer Indonesia di Papua yang disampaikan dalam beberapa kesempatan. Dengan kata lain, persepsi tentang Papua belum berubah menjadi positif meskipun strategi manajemen berita dan komunikasi strategis telah diupayakan Indonesia. Upaya mengubah persepsi mengenai isu Papua lantas menjadi tantangan sendiri dalam implementasi diplomasi publik Indonesia terhadap Vanuatu.

Dalam hal ini, upaya diplomasi publik dilakukan Indonesia dengan memberikan bantuan kepada Vanuatu yang terkena bencana Badai Pam pada tahun 2015. Bantuan tersebut berhasil menurunkan agresifitas Vanuatu dalam menyerang Indonesia terkait isu Papua, bahkan Sato Kilman sebagai Perdana Menteri Vanuatu pada saat itu bersedia menerima ide pembukaan kedutaan besar Indonesia di Vanuatu (Temaluru, 2016). Bantuan luar negeri tersebut menitipkan pesan bahwa Indonesia memiliki solidaritas dan kepedulian atas bencana alam yang menimpa rakyat Vanuatu.

Tahap ketiga yaitu pelibatan masyarakat Vanuatu dalam aktivitas yang diselenggarakan pemerintah Indonesia. Pencapaian diplomasi publik Indonesia pada tahap ini dapat dijumpai dalam terselenggaranya program Beasiswa Seni dan Budaya Indonesia (BSBI) dan berbagai program pelatihan kerja sama teknis dalam bidang perikanan. Selain itu, kerja sama perdagangan bilateral menunjukkan tren positif dengan adanya surplus bagi Indonesia untuk ekspor di sektor non-migas (Buku Diplomasi, 2014). Dengan capaian tersebut, dapat dikatakan bahwa bahwa diplomasi publik Indonesia berhasil mencapai tahap ini. Sebagian besar kategori telah tercapai seperti peningkatan kerja sama di berbagai bidang dan pengenalan Indonesia lebih jauh lewat pendidikan dan pariwisata, walaupun belum 
terpenuhi pada kriteria memahami dan mengadopsi nilai-nilai Indonesia oleh publik Vanuatu.

Tahap keempat dari pencapaian diplomasi publik adalah keberhasilan memengaruhi masyarakat di negara sasaran untuk mengikuti kemauan negara pelaksana diplomasi publik. Kerja sama antara Indonesia dan Vanuatu telah terjalin di berbagai bidang, seperti kerja sama pembangunan, pertanian, pengolahan produk hasil laut, pelatihan diplomatik, dan lain-lain. Selain itu, dari beberapa capaian utama hubungan Indonesia dan Vanuatu hingga tahun 2014 disebutkan bahwa perdagangan bilateral antara kedua negara menunjukkan tren positif dengan surplus bagi Indonesia untuk ekspor di sektor non-migas (Buku Diplomasi, 2014).

Akan tetapi, sikap politik Vanuatu baik pada tataran pemerintahan, elit politik, maupun masyarakat masih menunjukkan kecenderungan untuk mendukung upaya pemerdekaan Papua. Pemerintah Vanuatu dalam sejumlah forum baik di tingkat regional seperti forum MSG dan Pacific Island Forum (PIF) maupun forum internasional seperti sidang umum PBB, masih mengangkat isu pelanggaran HAM di Papua yang menyudutkan Indonesia. Elit Vanuatu juga menunjukkan sikap politik serupa dengan mendukung upaya pemerdekaan Papua. Sejumlah aktivis Vanuatu pro pemerdekaan Papua juga tergabung dalam perkumpulan seperti Asosiasi Vanuatu untuk Pembebasan Papua Barat (VFWPA). Tidak hanya itu, dukungan atas pemedekaan Papua juga ditunjukkan dalam pertemuan yang digelar pada tanggal 2-3 Mei 2016, di Port Vila, Vanuatu, dengan dilakukannya pengibaran Bendera Bintang Fajar di depan Gereja Presbyterian yang letaknya tidak jauh dari kantor MSG (Tempo, 2016). Sebelumnya, pada 29 April 2016, ratusan warga Vanuatu juga mengadakan demonstrasi sebagai bentuk solidaritas sesama "saudara Melanesia" untuk Papua Barat.

Dengan adanya kecenderungan ini, dapat disimpulkan bahwa diplomasi publik Indonesia belum berhasi memengaruhi publik Vanuatu. Strategi diplomasi Indonesia baik melalui manajemen berita, komunikasi strategis maupun pembangunan relasi terhadap masyarakat Vanuatu dalam isu Papua belum mampu membuat publik Vanuatu memihak dan mendukung sikap politik Indonesia. 
Dari keempat tahap pencapaian diplomasi publik di atas, terlihat bahwa upaya diplomasi yang dilakukan Indonesia masih berada pada tahap ketiga yakni pelibatan masyarakat Vanuatu dalam berbagai aktivitas yang diselenggarakan pemerintah Indonesia. Hal ini ditunjukkan oleh beberapa indikator seperti program pelatihan teknis, pemberian beasiswa, serta bantuan luar negeri kepada Vanuatu. Dapat dikatakan bahwa tahapan pertama diplomasi publik Indonesia terhadap Vanuatu telah terpenuhi, sementara untuk tahapan kedua belum seluruhnya tercapai karena adanya kriteria yang tidak terpenuhi, yaitu berubahnya persepsi publik Vanuatu tentang permasalahan di Papua. Demikian halnya pada tahap ketiga, yaitu adopsi terhadap nilai-nilai Indonesia yang belum terjadi dalam masyarakat Vanuatu. Penulis melihat, selain keterlibatan aktor dan strategi yang dijalankan, terdapat faktor lain yang menjadi penghambat belum tercapainya tahap keempat dari diplomasi publik Indonesia terhadap Vanuatu dalam isu Papua, yaitu faktor identitas dan nilai yang disebut Melanesian Renaissance.

\section{Kesimpulan: Kelemahan Diplomasi Publik Indonesia ter- hadap Vanuatu dalam Isu Papua}

Penelitian ini mengungkap bahwa gagalnya diplomasi publik Indonesia untuk memengaruhi sikap politik Vanuatu atas isu Papua disebabkan oleh belum optimalnya strategi diplomasi publik yang dijalankan Indonesia, baik pada dimensi manajemen berita, komunikasi strategis, maupun pembangunan hubungan. Tidak optimalnya ketiga dimensi tersebut menyebabkan diplomasi publik Indonesia tidak mampu memengaruhi perpolitikan domestik Vanuatu.

Penulis mengidentifikasi bahwa tidak optimalnya pelaksanaan diplomasi publik Indonesia terhadap Vanuatu dalam isu Papua dipengaruhi oleh tiga hal.

Pertama, variabel aktor pelaksana diplomasi publik Indonesia terhadap Vanuatu, baik pada dimensi manajemen berita, komunikasi strategis maupun pembangunan relasi masih didominasi oleh aktor negara (first track). Sementara peran aktor non-negara (second track) seperti LSM, bisnis, aktivis, peneliti, media dll (Diamond dan McDonald 1996) masih minim, bahkan tidak terlihat sama sekali pada dimensi pembangunan relasi. Padahal diplomasi publik dapat 
tercapai dengan maksimal jika dilakukan oleh pemerintah dan disokong oleh aktor-aktor lainnya.

Kurang terlihatnya peran aktor non-negara menurut penulis dipengaruhi oleh aspek waktu atau timeline pelaksanaan diplomasi publik. Dari penelusuran literatur, pelaksanaan diplomasi publik Indonesia terhadap Vanuatu terutama pada dimensi manajemen berita dan komunikasi strategis, baru dijalankan secara masif pada tahun 2013, yaitu sejak Vanuatu semakin gencar dan vokal "menyerang" Indonesia mengenai isu Papua dalam berbagai forum regional maupun internasional. Hal ini berarti bahwa pelaksanaan diplomasi publik ini tergolong baru, sehingga pelibatan aktor non-negara belum banyak dilakukan.

Kedua, pelaksanaan ketiga dimensi diplomasi publik tidak didukung oleh lembaga khusus yang secara fokus dan terkoordinasi menjalankan ketiga dimensi sesuai indikator yang ada. Hal ini menyebabkan dimensi manajemen berita dan komunikasi strategis dijalankan secara sporadis, tidak terkordinasi dan berkelanjutan, serta target audiens atau pembaca berita tidak tepat sasaran. Media yang berperan dalam manajemen berita masih berorientasi pada bisnis pemberitaan. Pembentukan lembaga khusus ini sejatinya penting. Salah satunya dapat dilihat pada upaya diplomasi publik pemerintah Inggris yang menjalankannya dengan membentuk institusi-institusi selain kedutaan (embassy), seperti British Council, Department for International Development (DFID), The Foreign and Commonwealth Office (FCO), dan Trade Partners United Kingdom (TPUK) (Leonard, Stead, dan Smewing 2002). Sementara di Indonesia, diplomasi publik hanya dijalankan oleh institusi kedutaan besar (Kedubes) dan diplomat dari Kementerian Luar Negeri (Kemenlu RI) serta aktor-aktor non-negara.

Ketiga, pelaksanaan diplomasi publik Indonesia terhadap Vanuatu juga terhambat dengan adanya doktrin Melanesian Renaissance. Doktrin ini merupakan identitas sekaligus cita-cita bersama ras Melanesia yang berporos pada kesamaan sejarah, etnis dan budaya dalam membangun nasionalisme negara-negara serumpun (Temaluru 2016). Doktrin Melanesian Renaissance yang dipegang kuat sejak kemerdekaan Vanuatu ini menanamkan keyakinan dalam diri setiap rakyat Vanuatu bahwa bangsa Melanesia lainnya harus be- 
bas dari penjajahan. Faktor Melanesian Renaissance erat pula kaitannya dengan ambisi Vanuatu menjadi pemimpin regional bagi negara-negara Melanesia (Temaluru 2016). Dengan dalih kesamaan ras, Vanuatu lantas menempatkan diri pada garis terdepan dalam perjuangan kemerdekaan Papua untuk mewujudkan misi Vanuatu sebagai pemimpin di kawasan Pasifik Selatan.

Kuatnya doktrin Melanesian Renaissance ini menjadi penghambat masuknya diplomasi publik Indonesia dalam perpolitikan Vanuatu. Salah satu mantan Perdana Menteri Vanuatu, Sato Kilman, bahkan dilengserkan melalui mosi tidak percaya oleh Parlemen Vanuatu pada tahun 2013 karena dianggap telah mengabaikan Melanesian Renaissance dengan menjalin hubungan politik yang erat dengan Indonesia. Mosi ini muncul karena dalam beberapa kesempatan, Kilman menyampaikan bahwa Indonesia adalah partner penting dan strategis bagi Vanuatu (Temaluru 2016). Selain itu, bantuan ekonomi dari Indonesia untuk bencana Cyclone Pam tahun 2015 juga diberikan pada masa pemerintahan Sato Kilman. Oleh karena itu, penulis menilai bahwa narasi-narasi Melanesia yang mulai dibangun Indonesia melalui pembentukan Indonesian Melanesian Brotherhood dan penyelenggaraan Melanesian Cultural Festival tidak akan mampu mengubah sikap politik Vanuatu. Kendati demikian, Indonesia masih mempunyai peluang apabila mampu mengoptimalkan tiga dimensi diplomasi publik yang ada, mengelola dan mengoordinasikan pelaksanaan diplomasi publik secara profesional, serta melibatkan lebih banyak aktor non-negara. 


\section{Referensi}

ABC News, 2014. "Vanuatu pushes UN to investigate allegations of rights abuses in Papua", $A B C$ News, 5 Maret [online]. dalam http://www.abc.net.au/news/2014-03-05/vanautu-urges-human-rights-investigation/5301270 [diakses 1 Maret 2017]..

Badan Intelijen Negara (BIN), 2014. Menyongsong 2014 - 2019: Memperkuat Indonesia dalam Dunia yang Berubah. Jakarta: CV Rumah Buku.

Diamond, L \&dan J. McDonald, 1996. Multi-Track Diplomacy: A Systems Approach to Peace-Third Edition. West Hartford: Kumarian Press.

Direktorat Informasi dan Media Direktorat Jenderal Informasi dan Diplomasi Publik, 2014. Diplomasi Indonesia 2014. Jakarta: Kementerian Luar Negeri Republik Indonesia.

Dorney, Sean, 2013. "Vanuatu to terminate Indonesia defence agreement", $A B C$ News, 12 April [online]. dalam http://www.abc. net.au/news/2013-04-12/vanuatu-pm-to-terminate-indonesiaagreement/4626410 [diakses ].

Kementerian Luar Negeri (Kemenlu), 1995. "Joint Communique Concerning the Establishment of Diplomatic Relations Between the Republic of Indonesia and the Republic of Vanuatu" [online]. dalam http://treaty.kemlu.go.id/apisearch/ pdf?filename=VUT-1995-0001.pdf [diakses 1 Maret 2017]..

, 2016. "No Genocide in West

Papua” [online]. dalam https://www.kemlu.go.id/wellington/ Documents/No\%20Genocide\%20in\%20West\%20Papua.pdf [diakses 13 September 2017]..

Fokus-dan-Siap-Bantu-Situasi-HAM-Domestiknya” [online]. dalam http://kemlu.go.id/id/berita/berita-perwakilan/Pages/ RI-Dorong-Vanuatu-untuk-Fokus-dan-Siap-Bantu-SituasiHAM-Domestiknya.aspx [diakses 13 September 2017].

Leonard, M., Stead, C., \&dan C. Smewing, 2002. Public Diplomacy. London: The Foreign Policy Centre.

McHenry, DE., 2009. "Does Globalization Cause Separatism? 
A Critical Examination of the Globalization-Separatism Relationship.”, dalam the 21st World Congress of the International Political Science Association, Santiago, Chile.

Papua Review, 2012. "Lima Masalah Mendasar di Papua," Papua Review, 02 (1).

Puspitasari, Irfa, 2010. " Indonesia's New Foreign Policy - 'Thousand Friends - Zero Enemy”, IDSA Issue Brief [online]. dalam https://idsa.in/system/files/IB IndonesiaForeignPolicy.pdf [diakses 13 September 2017].

Rahman, Mustafa Abd, 2017. "Politisasi Isu HAM di Papua, Vanuatu didesak Fokus Masalah HAM Sendiri.", Kompas, 02 Maret [online]. dalam http://internasional.kompas.com/ read/2017/03/02/21030521/politisasi.isu.ham.di.papua.vanuatu.didesak.fokus.masalah.ham.sendiri [diakses 7 September 2017]..

Rappler, 2016. "Pelanggaran HAM di Papua diungkit kembali di Sidang Majelis Umum PBB ke-71.”, Rappler, 02 Oktober [online]. dalam https://www.rappler.com/indonesia/147970-pelanggaran-ham-papua-sidang-umum-pbb [diakses 1 Maret 2017].

Tebay, N., 2016. "Pertarungan Indonesia versus Papua”, Tempo, 27 Juli.

Temaluru, T. B. P., 2016. "Kepentingan Vanuatu dalam Usaha Pemerdekaan Papua.", Jurnal Analisis Hubungan Internasional, 5 (2) : 572-583.

ULMWP. "About ULMWP" [online]. dalam https://www.ulmwp. org/about-ulmwp [diakses 11 Januari 2017]. 